\title{
ANALISIS PENGARUH FAKTOR PRODUKSI TERHADAP PRODUKTIVITAS USAHATANI KELAPA SAWIT POLA SWADAYA DI DESA SUNGAI BULUH KECAMATAN KUANTAN SINGINGI HILIR, KABUPATEN KUANTAN SINGINGI
}

\section{Analysis of the Effect of Production Factors on Productivity of Oil Palm Farming with Swadaya Pattern in Sungai Buluh Village, Kuantan Singingi Hilir District, Kuantan Singingi Regency}

\author{
Edward Panjaitan, Ujang Paman dan Darus \\ Fakultas Pertanian Universitas Islam Riau, \\ J1. Kaharuddin Nasution No. 113 P. Marpoyan, Pekanbaru 28284 Riau \\ Email : edwardpanjaitan15@gmail.com \\ [Diterima Desember 2019, disetujui April 2020]
}

\begin{abstract}
Palm oil is one of the potential commodities that is widely cultivated by farmers in Singingi Hilir Regency. This study aims to analyze the farmers' characteristics and profile of oil palm farming, the use of factors of production, costs, production, income and efficiency of oil palm farming, and the effect of production factors on oil palm farming productivity. The research was conducted during 6 months, starting from September 2018 to February 2019. Survey location was selected in Sungai Buluh Village Kuantan Singingi Hilir District Kuantan Singingi Regency and samples were purposively selected as 38 farmers. The samples were farmers who have oil palm farming with age between 10-15 years. Data were collected by survey method, consisting of primary data and secondary data. The results showed that the average age of farmers was 46.32 years, the education level of farmers averaged 9.61 years, the average number of family members was 4 person with having experience on oil palm cultivation was 13.84 years. The average of farmers' land area was 3.63 ha. The average of oil palm production cost was IDR 40,227,034/year, consisting of variable costs of IDR 39,818,783 and fixed costs of IDR 408,251. The average of oil palm production in fresh fruit bunch was $64,740 \mathrm{~kg} / \mathrm{year}$ with a selling price of IDR $1,449 / \mathrm{kg}$ and revenue was IDR 93,813,371/year. Moreover, the profit obtained was IDR 53,586,337/year and efficiency value (RCR) was 2.33. The land area and urea fertilizer had a significant effect on palm oil productivity in Sungai Buluh Village, Singingi Hilir District, Kuantan Singingi Regency.
\end{abstract}

Keywords:Production factors, Oil palm farming, Productivitas, Swadya pattern.

\begin{abstract}
ABSTRAK
Kelapa sawit adalah salah satu komoditas potensial yang banyak dibudidayakan di Kabupaten Kuantan Singingi. Penelitian ini bertujuan untuk menganalisis karakteristik petani dan profil usahatani kelapa sawit, penggunaan faktor-faktor produksi, biaya, produksi, pendapatan dan efisiensi pertanian kelapa sawit, dan faktor-faktor yang mempengaruhi produktivitas usahatani kelapa sawit. Penelitian dilakukan selama 6 bulan yang mulai dari bulan September 2018 hingga Februari 2019. Lokasi penelitian ditetapkan di Desa Sungai Buluh Kecamatan Kuantan Singingi Hilir Kabupaten Kuantan Singingi. Petani sampel dipilih secara sengaja sebanyak 38 orang petani yang mempunyai usahatani kelapa sawit pola swadaya berumur 10-15 tahun. Data dikumpulkan dengan metode survei yang terdiri dari data primer dan data sekunder. Hasil penelitian menunjukkan bahwa petani kelapa sawir mempunyai umur rata-rata 46,32 tahun, tingkat pendidikan rata-rata 9,61 tahun, jumlah anggota keluarga rata-rata 4 orang dengan pengalaman dalam mengelola kelapa sawit selama13,84 tahun. Luas rata-rata usahatani kelapa sawit adalah 3,63 ha. Biaya produksi rata-rata adalah Rp. 40.227.034 per tahun yang terdiri dari biaya variabel Rp. 39.818.783, dan biaya tetap Rp. 408.251). Rata-rata produksi dalam bentuk tandan buah segar (TBS) sebanyak $64.740 \mathrm{~kg} /$ tahun dengan harga jual $\mathrm{Rp}$ 1.449/kg. Pendapatan kotor yang diperoleh sebasar Rp. 93.813.371/tahun, sedangkan laba bersih sebasar Rp. 53.586.337/tahun dengan nilai efisiensi (RCR) sebesar 2,33. Luas lahan dan pupuk urea
\end{abstract}


merupakan faktor yang berpengaruh secara signifikan terhadap produktivitas kelapa sawit in Desa Sungai Buluh, Kecamatan Singingi Hilir, Kabupaten Kuantan Singingi.

Kata Kunci: Faktor produksi, Usahatani kelapa sawit, Produktivitas, Pola swadaya

\section{PENDAHULUAN}

Di Indonesia, tanaman kelapa sawit memiliki arti penting dalam pembangunan perekonomian nasional. Selain mampu menciptakan kesempatan kerja dan berusaha, perkebunan kelapa sawit juga merupakan salah satu sumber devisa negara dari hasil ekspor crude palm oil (CPO). Indonesia merupakan salah satu produsen utama minyak kelapa sawit dunia. Pengembangan komoditas ekspor kelapa sawit terus meningkat dari tahun ke tahun, terlihat dari rata-rata laju pertumbuhan luas areal kelapa sawit selama 2004-2014 meningkat sebesar 7,67\%, sedangkan produksi kelapa sawit meningkat rata-rata $11,09 \%$ per tahun. Peningkatan luas areal tersebut disebabkan oleh harga $\mathrm{CPO}$ yang relatif stabil di pasar internasional dan memberikan pendapatan bagi produsen, khususnya petani dengan cukup menguntungkan (BPS, 2014).

Berdasarkan buku statistik komoditas kelapa sawit pada tahun 2016 luas areal kelapa sawit mencapai 11,20 juta ha dengan produksi CPO sebanyak 31,49 juta ton. Dimana dari luas areal tersebut, sebesar $42,31 \%$ adalah perkebunan milik rakyat (Perkebunan Rakyat), 51,37\% milik swasta, dan sisanya sebesar $6,32 \%$ adalah milik negara (BPS, 2017).

Riau merupakan provinsi yang kaya akan sumberdaya alam yang dapat dioptimalkan seperti sumberdaya pertanian/ perkebunan. Dengan potensi sumber daya alam yang luas tersebut, usaha pertanian di Riau sangat menjanjikan secara ekonomi. Salah satu usaha tersebut adalah perkebunan kelapa sawit yang paling banyak dilakukan oleh masyarakat Riau sekarang ini. Provinsi Riau merupakan salah satu provinsi di Indonesia yang memiliki luas lahan dan produksi kelapa sawit tertinggi. Menurut data Direktorat Jendral Perkebunan (2015), luas kebun kalapa sawit di Provinsi Riau mencapai 2.296.894 ha atau $21,49 \%$ dengan jumlah produksi 7.037.639 ton atau 24,31\%.

Kecamatan Singingi Hilir merupakan salah satu sentra produksi TBS dengan luas lahan terluas di Kabupaten Kuantan Singingi Provinsi Riau. Pada tahun 2016 luas areal perkebunan kelapa sawit di Kecamatan Singingi Hilir yaitu sebesar 24.789 ha atau sekitar 19\% dari total luas areal perkebunan kelapa sawit yang ada di Kabupaten Kuantan Singingi. Meskipun Kecamatan Singingi Hilir memiliki luas lahan tertinggi di Kabupaten Kuantan Singingi, namun tidak serta merta menghasilkan produksi TBS yang tertinggi pula. Hal ini ditunjukkan dari produksi TBSnya yang hanya sebanyak 75.138 ton lebih rendah dibandingkan produksi TBS di Kecamatan Kuantan Mudik yang mencapai 92.735 ton dengan luas areal yang lebih kecil yaitu 19.407 ha. Hal ini disebabkan karena produktifitas kelapa sawit di Kecamatan Kuantan Mudik yaitu sebesar 4,78 ton/ha sedangkan di Singingi Hilir hanya sebesar 3,00 ton/ha.

Usahatani kelapa sawit yang produktif dan efisien akan mendorong penggunaan faktor produksi secara optimal, yang selanjutnya akan menentukan keuntungan yang akan diperoleh. Untuk mencapai keuntungan yang maksimal petani harus dapat menggunakan faktor produksi secara efisien. Efisien dalam proses usahatani mempunyai arti sangat penting dalam upaya peningkatan pendapatan petani kelapa sawit itu sendiri, dalam meren-canakan atau mengembangakan usahatani kelapa sawit yang efektif dan efisien.

Seiring dengan laju pertumbuhan penduduk saat ini, kebutuhan atau permintaan akan kelapa sawit akan tetap tinggi di masamasa mendatang. Hal ini disebabkan oleh meningkatnya permintaan CPO dan beberapa produksi turunan lainnya dari kelapa sawit. Oleh karena itu dalam upaya peningkatan produksi dan produktivitas, petani dituntut menggunakan faktor produksi yang optimal untuk meng-hasilkan produktivitas yang maksimal dan akhirnya berdanpak pada keuntungan yang diperoleh patani. Adapun permasalahan dalam penelitian ini dapat dirumuskan sebagai berikut. Pertama, bagaimana karak-teristik petani dan profil usahatani kepala sawit pola swadaya. Kedua, berapa banyak penggunaan faktor produksi, biaya, produksi, pendapatan dan efisiensi usaha-tani kelapa sawit. Ketiga, faktor-faktor 
apa saja yang mempengaruhi produksi usahatani kelapa sawit di Desa Sungai Buluh Kecamatan Singingi Hilir. Dari rumusan permasalahan di atas, maka tujuan pene-litian ini adalah bertujuan untuk menganalisis karakteristik petani dan profil usahatani kelapa sawit pola swadaya, penggunaan faktor produksi, biaya, produksi, pendapatan dan efisiensi usahatani kelapa sawit, dan faktorfaktor yang mempengaruhi produksi usahatani kelapa sawit di Desa Sungai Buluh Kecamatan Singingi Hilir.

\section{METODE PENELITIAN}

Penelitian ini menggunakan metode survei, yang dilaksanakan di Desa Sungai Buluh Kecamatan Singingi Hilir Kabupaten Kuantan Singingi. Desa ini dipilih dengan pertimbangan bahwa Desa Sungai Buluh merupakan sentra perkebunan kelapa sawit dan merupakan daerah pengembangan perkebunan kelapa sawit petani rakyat di Kecamatan Singingi Hilir Kabupaten Kuantan Singingi. Penelitian ini dilaksa-nakan selama 6 (enam) bulan yang dimulai mulai dari bulan September 2018 hingga Februari 2019.

Populasi dalam penelitian ini adalah seluruh petani kelapa sawit swadaya yang ada di Desa Sungai Buluh Kecamatan Singingi Hilir Kabupaten Kuantan Singi-ngi. Pengambilan sampel dilakukan secara sengaja (purposive) terhadap petani kelapa sawit swadaya, dengan kriteria bahwa tanaman kelapa sawit yang dimiliki telah berumur antara 10-15 tahun (berumur produktif). Dengan penggunaan kriteria tersebut, maka sampel pilih sebanyak 38 orang petani dari sebanyak 90 kepala keluarga (KK) petani kelapa sawit.

Data yang digunakan dalam penelitian ini adalah data primer dan data sekunder. Data primer diperoleh dengan wawancara langsung dengan petani sampel dengan berpedoman pada daftar pertanyaan yang telah disediakan sebelumnya. Hal ini dimaksudkan untuk mendapatkan informasi data lengkap dan akurat dari petani. Data primer yang dikumpulkan meliputi umur, tingkat pendidikan, jumlah anggota keluar-ga, luas lahan, jumlah penggunaan alat pertanian, tenaga kerja, jumlah pengguna-an faktor produksi (pupuk dan pestisida), produksi dan harga TBS.
Sedangkan, data sekunder yang dikumpulknan diperoleh dari lembaga atau instansi-instansi terkait dengan penelitian ini, seperti Badan Pusat Statistik, Dinas Pertanian/Perkebunan, Jurnal dan Skripsi. Data sekunder meliputi keadaan umum daerah penelitian, populasi petani kelapa sawit, luas lahan kelapa sawit, keadaan penduduk dan monografi desa.

Data yang telah dikumpulkan dari lapangan, kemudian ditabulasi dan diana-lisis dengan menggunakan pendekatan deskriptifkualitatif dan kuantitatif. Untuk data yang berkaitan dengan karakteristik petani dan profil usahatani pada tujuan pertama maka dianalsis dengan pendekatan deskriptifkualitatif. Sedangkan untuk tujuan kedua dan ketiga menggunakan analisis sebagai berikut:

\section{Biaya Produksi}

Untuk menghitung biaya produksi kelapa sawit maka digunakan rumus menurut (Soekartawi, 1995):

$T C=T V C+T F C \ldots \ldots \ldots \ldots \ldots \ldots \ldots \ldots \ldots \ldots \ldots \ldots$

$T C=(X 1 \cdot P X 1+X 2 \cdot P X 2+X 3 . P X 3)+D \ldots$

Keterangan:

$\begin{array}{ll}\text { TC } & \text { : Total biaya (Rp/tahun) } \\ \text { TVC } & \text { : Total biaya variabel (Rp/tahun) } \\ \text { TFC } & \text { : Total biaya tetap (Rp/tahun) } \\ \text { X1 } & \text { : Penggunaan pupuk (kg/tahun) } \\ \text { PX1 } & \text { : Harga pupuk (Rp/kg) } \\ \text { X2 } & \text { : Penggunaan TK (HOK/tahun) } \\ \text { PX2 } & \text { : Upah TK (Rp/HOK) } \\ \text { X3 } & \text { : Penggunaan pestisida (ltr/tahun) } \\ \text { PX3 } & \text { : Harga pestisida (Rp/liter) } \\ \text { D } & \text { : Penyusutan alat (Rp/tahun) }\end{array}$

Penyusutan Alat

Untuk menghitung penyusutan alatalat pertanian digunakan rumus (Hernanto, 1991):

$D=(N B-N S) / M P$

Keterangan:

D : Depresiasi atau penyusutan alat dan mesin (Rp/unit/tahun)

NB : Harga beli (Rp/unit)

NS : Nilai sisa $(20 \%$ dari harga beli $)$ (Rp/unit/tahun)

MP : Masa pakai (tahun)

\section{Pendapatan}

Pendapatan kotor usahatani kelapa sawit diperoleh dengan menggunakan ru-mus (Hernanto, 1996): 
$T R=Y . P y$

Keterangan:

TR: Pendapatan kotor kelapa sawit (Rp/garapan/tahun)

Y : Produksi TBS (kg/garapan/tahun)

Py : Harga TBS $(\mathrm{Rp} / \mathrm{kg})$

Untuk menghitung pendapatan bersih usahatani kelapa sawit maka digunakan rumus (Hernanto, 1996):

$\pi=T R-T C$.

Keterangan:

$\pi$ : Pendapatan bersih usahatani kelapa sawit (Rp/garapan/tahun)

TR : Pendapatan kotor kelapa sawit (Rp/garapan/tahun)

TC : Total biaya kelapa sawit (Rp/garapan/tahun)

\section{Efisiensi Usahatani}

Untuk mengetahui apakah efisiensi usahatani itu layak atau tidak diukur dengan nilai RCR dari usahatani tersebut. Efisiensi dihitung dengan menggunakan analisis Return Cost Ratio (RCR) dengan rumus menurut (Hernanto, 1991):

$R C R=T R / T C$.

Keterangan:

RCR: Return Cost Ratio

TR : Total penerimaan (Rp/garapan/tahn)

TC : Total biaya (Rp/garapan/tahun)

Dengan kriteria:

RCR > 1 : Berarti usahatani kelapa sawit menguntungkan.

$\mathrm{RCR}=1 \quad$ : Berarti usahatani kelapa sawit berada pada titik impas.

$\mathrm{RCR}<1$ : Berarti usahatani kelapa sawit tidak menguntungkan.

\section{HASIL DAN PEMBAHASAN}

\section{Karakteristik Petani}

Rata-rata umur petani kelapa sawit pola swaadaya diperoleh sebesar 46,31 tahun dengan kisaran 15 - 64 tahun, hal ini menunjukkan bahwa rata-rata petani di Desa Sungai Buluh berumur produktif. Umur petani terbanyak pada rentang umur 46 - 50 tahun dengan jumlah sebanyak 11 orang petani atau $28,95 \%$ dari jumlah responden.

Sebagian besar lamanya pendidikan petani kelapa sawit pola swadaya di Desa Sungai Buluh adalah pada kisaran tahun 7-9 tahun (setara SMP) sebanyak 16 orang dengan persentase 42,11\%, sedangkan tingkat pendidikan dengan jumlah terendah yaitu $>12$ tahun sebanyak 1 orang dengan persentase $2,63 \%$. Rata-rata pendidikan petani diperoleh 10,07 (setara 1 SMA), artinya pendidikan formal petani kelapa sawit di Desa Sungai Buluh sudah berada pada tingkat menengah ke atas. Pendidikan ini sangat mempengaruhi sikap dan keputusan yang akan diambil, terutama dalam menerapkan inovasi baru yang pada akhirnya akan berpengaruh terhadap produksi dan pendapatan petani kelapa sawit.

Sebagian besar pengalaman petani dalam berusahatani kelapa sawit di Desa Sungai Buluh yaitu pada kisaran 13-14 tahun, dengan jumlah yahitu sebanyak 12 petani atau sebesar $31,58 \%$. Rata-rata pengalaman usahatani diperoleh yaitu sebesar 13,36 tahun, hal ini sekaligus menunjukkan bahwa rata-rata petani sudah berpengalaman cukup lama dalam menja-lankan usahatani kelapa sawit. Semakin lama petani menekuni usahatani yang dilakukan maka semakin meningkat pula pengetahuan dan keterampilan dalam mengelola usahataninya.

Jumlah anggota keluarga yang menjadi tanggungan keluarga petani kelapa sawit di Sungai Buluh sebagian besar sebanyak 4 orang dengan jumlah 15 orang petani yang bekerja sebagai tulang pung-gung keluarga atau dengan persentase $39,47 \%$. Rata-rata jumlah tanggungan keluarga diperoleh yaitu sebanyak 4,5 (5 orang).

Luas lahan yang digunakan pada usahatani kelapa sawit di Desa Sungai Buluh sebagian besar memiliki luas dalam rentang 4 - 5 ha dengan jumlah petani sebanyak 28 orang atau $73,68 \%$ dari jumlah keseluruhan petani. Rata-rata luas lahan yang diusahakan petani seluas 3,63 ha.

\section{Biaya, Pendapatan dan Efisiensi Usahatani}

Adapun hasil analisis biaya, produksi, pendapatan, dan efisiensi usahatani kelapa sawit di Desa Sungai Buluh dapat dilihat pada Tabel 1.

\section{Biaya Tetap}

Biaya tetap (fixed cost) merupakan biaya yang besar kecilnya tidak tergantung kepada volume produksi, sehingga berapapun besar produksi selama berada pada kapasitasnya maka biaya produksi tidak akan berubah-ubah setiap tahunnya. Biaya tetap yang dihitung dengan meng-gunakan mtode garis lurus disajikan dala Tabe 1. Pada Tabel 1 
dapat diketahui bahwa nilai penyusutan alat pada usaha tani kelapa sawit rata-ratayaitu sebesar $\mathrm{Rp}$ 408.251/tahun (1,01\%). Dimana alat yang digunakan meliputi eggrek, angkong, cangkul, gancu, kapak, dodos, babat, dan hand sprayer.

Biaya Produksi

Biaya variabel (variable cost) merupakan biaya yang besar kecilnya tergantung kepada volume produksi, dimana biaya ini dihitung per luas garapan petani setiap tahunnya. Pada Tabel 1 dapat diketahui bahwa pupuk merupakan biaya terbesar dari total biaya variabel yang dikeluarkan dalam usaha tani kelapa sawit di Desa Sungai Buluh yaitu sebesar Rp. 29.766.842/tahun atau sebesar $74 \%$ dari total biaya produksi.

Tabel 1. Rataan Biaya, Pendapatan dan Efisiensi Usahatani Kelapa Sawit di Desa Sungai Buluh Kecamatan Singingi Hilir Tahun 2018

\begin{tabular}{|c|c|c|c|c|c|}
\hline No & Uraian & Jumlah & $\begin{array}{c}\text { Harga } \\
\text { (Rp/satuan) }\end{array}$ & $\begin{array}{c}\text { Nilai } \\
(\text { Rp/garapan/thn })\end{array}$ & $\operatorname{Persen}(\%)$ \\
\hline \multirow[t]{15}{*}{ A } & Biaya total & & & 40.227 .034 & 100,00 \\
\hline & 1. Biaya variabel & & & 39.818 .783 & 98,99 \\
\hline & a. Pupuk & & & 29.766 .842 & 74,00 \\
\hline & 1) $\mathrm{TSP}(\mathrm{Kg})$ & 1.784 & 6.000 & 10.705 .263 & 26,61 \\
\hline & 2) Urea (Kg) & 1.674 & 5.500 & 9.205 .263 & 22,88 \\
\hline & 3) $\mathrm{KCl}(\mathrm{Kg})$ & 1.616 & 6.100 & 9.856 .316 & 24,50 \\
\hline & b. Pestisida & & & 2.073 .026 & 5,15 \\
\hline & 1) Gramoxon (Liter) & 9,78 & 70.000 & 684.342 & 1,70 \\
\hline & 2) Round-up (Liter) & 9,53 & 75.000 & 714.474 & 1,78 \\
\hline & 3) Herbatop (Liter) & 9,63 & 70.000 & 674.211 & 1,68 \\
\hline & c. Tenaga Kerja & & & 7.978 .914 & 19,83 \\
\hline & 1) TKDK (HOK) & 37,08 & & 2.578 .520 & 6,41 \\
\hline & 2) TKLK (HOK) & 62,58 & & 5.400 .395 & 13,42 \\
\hline & 2. Biaya tetap & & & 408.251 & 1,01 \\
\hline & a. Penyusutan alat (Rp) & 64.740 & 1.449 & 408.251 & 1,01 \\
\hline $\mathrm{B}$ & Pendapatan kotor $(\mathrm{Rp})$ & & & 93.813 .371 & \\
\hline $\mathrm{C}$ & Pendapatan bersih (Rp) & & & 53.586 .337 & \\
\hline $\mathrm{D}$ & RCR & & & 2,33 & \\
\hline
\end{tabular}

Biaya pupuk tersebut terdiri atas pupuk TSP Rp. 10.705.263/tahun, pupuk urea Rp. 9.205.263/tahun, dan pupuk $\mathrm{KCl} \mathrm{Rp}$. 9.856.316/tahun. Sedangkan biaya lainnya yaitu pestisida sebesar Rp. 2.073.026/tahun yang terdiri dari gramoxon Rp. 684.342/tahun, round-up Rp. 714.474/ tahun, herbatop $\mathrm{Rp}$ $674.211 /$ tahun atau sebesar 5,15\%; dan tenaga kerja sebesar Rp. 7.978.914/tahun (19,83\%).

Pendapatan

Pedapatan yang dianalisis dalam penelitian ini terdiri atas dua yaitu pendapatan kotor (gross income) dan pendapatan bersih (net income). Pendapatan ini juga dihitung per luas garapan petani per tahunnya. Berdasarkan Tabel 1 dapat dilihat pendapatan kotor dari hasil penjualan TBS yaitu sebesar Rp 93.813.371/tahun dengan harga jual Rp. 1.449 dan produksi sebesar $64.740 \mathrm{~kg} /$ tahun, sedangkan pendapatan bersih diperoleh petani sebesar Rp 53.586.337/tahun.

Efisiensi
Pada Tabel 1 dapat dilihat bahwa nilai efisensi usahatani kelapa sawit yang dihitung dengan pendekatan RCR di daerah penelitian diperoleh 2,33. Ini artinya bahwa setiap Rp. 1 yang dikeluarkan untuk usahatani kelapa sawit akan diperoleh pendapatan korot sebedar Rp, 2,33 atau pendaoatan bersih sebesar Rp 1,33. Hal ini mengindikasikan bahwa usahatani kelapa sawit menguntungkan dan layak untuk diusahakan.

\section{Faktor-Faktor yang Mempengaruhi Produksi Kelapa Sawit}

Untuk mengetahui faktor-faktor yang berpengaruh secara nyata pada produksi digunakan fungsi produksi Cobb-Douglass dengan menggunakan model linear berganda (Multiple Linear Regression) dan dianalisis dengan bantuan program SPSS.

Luas Lahan

Lahan merupakan faktor produksi utama dalam usaha tani kelapa sawit karena 
lahan menjadi bakal tempat tumbuh dan berkembangnya tanaman kelapa sawit. Koefisien regresi luas lahan kelapa sawit diperoleh sebesar 1,110 yang berarti bahwa setiap peningkatan luas lahan kelapa sawit sebesar $1 \%$, akan meningkatkan produksi kelapa sawit sebesar $1,11 \%$, dengan faktor lain dianggap tetap (cateris paribus).
Sebaliknya apabila ada penurunan luas lahan sebesar $1 \%$ maka akan menurunkan produksi kelapa sawit sebesar $1,11 \%$. Nilai Sig diperoleh sebesar $0,000(<$ taraf signifikansi $0,05)$, maka artinya variabel luas lahan berpengaruh signifikan (nyata) terhadap produksi kelapa sawit di Desa Sungai Buluh.

Tabel 2. Hasil Estimasi Regresi Linear Berganda Faktor-faktor yang Mempengaruhi Produksi Kelapa Sawit Swadaya di Desa Sungai Buluh Tahun 2018

\begin{tabular}{clllll}
\hline No & \multicolumn{1}{c}{ Model } & Coefficients & \multicolumn{1}{c}{ T-hitung } & \multicolumn{1}{c}{ Sig } & VIF \\
\hline 1 & Constant & 12,377 & 19,030 & 0,000 & \\
2 & LN_Luas Lahan (X1) & 1,110 & 9,620 & $0,000^{*}$ & 9,526 \\
3 & LN_Tenaga Kerja (X2) & $-0,067$ & $-1,007$ & 0,322 & 1,546 \\
4 & LN_Urea (X3) & $-0,147$ & $-2,358$ & $0,025^{*}$ & 2,150 \\
5 & LN_TSP (X4) & $-0,118$ & $-1,895$ & 0,068 & 2,172 \\
6 & LN_KCL (X5) & 0,001 & 0,023 & 0,982 & 1,586 \\
7 & LN_Pestisida (X6) & $-0,080$ & $-1,828$ & 0,077 & 9,343 \\
\hline F-Statistic & 66,962 & & \\
\hline F-Sig & 0,000 & & \\
\hline R-Squared (R2) & 0,928 & & \\
\hline Adjust R-Squared & 0,915 & & \\
\hline Durbin-Watson (D-W) & 1,785 &
\end{tabular}

Tenaga Kerja

Tenaga kerja menentukan keberhasilan produksi yang diusahakan karena tenaga kerja sangat dibutuhkan dalam membantu kegiatan yang ada di kebun. Koefisien regresi variabel tenaga kerja diperoleh sebesar $-0,067$ yang berarti bahwa setiap peningkatan penggunaan tenaga kerja sebesar $1 \%$, maka akan menurunkan produksi kelapa sawit sebesar $0,067 \%$, dengan faktor lain dianggap tetap (cateris paribus). Sebaliknya apabila ada penurunan penggunaan tenaga kerja sebesar $1 \%$, maka akan meningkatkan produksi kelapa sawit sebesar 0,067\%. Nilai Sig diperoleh sebesar 0,322 (> taraf signifikansi 0,05), maka artinya variabel tenaga kerja tidak berpengaruh signifikan (nyata) terhadap produksi kelapa sawit di Desa Sungai Buluh dan sebaiknya peng-gunaan tenaga kerja yang berlebihan harus dikurangi supaya hasil yang diperoleh efisien.

Pupuk Urea

Koefisien regresi variabel pupuk urea diperoleh sebesar -0.147 yang berarti bahwa setiap peningkatan penggunaan pupuk urea sebesar $1 \%$ maka akan menurunkan produksi kelapa sawit sebesar $0.147 \%$, dengan faktor lain dianggap tetap (cateris paribus). Sebaliknya apabila ada penurunan penggunaan pupuk urea sebesar $1 \%$ maka akan meningkatkan produksi kelapa sawit sebesar $0,067 \%$. Nilai sig diperoleh sebesar 0,025 (<taraf signifikansi 0,05), maka artinya variabel pupuk urea berpengaruh signifikan (nyata) terhadap produksi kelapa sawit di Desa Sungai Buluh.

Sesuai rekomendasi pupuk dari Litbang Perkebunan penggunaan pupuk urea yaitu $358 \mathrm{~kg} / \mathrm{garapan} / \mathrm{tahun}$ berban-ding terbalik dengan hasil yang ada di lapangan. Petani swadaya menggunakan pupuk urea 461 $\mathrm{kg} /$ garapan/tahun, dari hasil perbandingan tersebut petani swadaya masih belum menggunakan pupuk secara tepat jumlah sesuai rekomendasi sehingga akan dapat menurunkan produksi kelapa sawit.

Pupuk TSP

Koefisien regresi variabel pupuk TSP diperoleh sebesar $-0,118$ yang berarti bahwa setiap peningkatan penggunaan pupuk TSP sebesar $1 \%$ maka akan menurunkan produksi kelapa sawit sebesar $0,118 \%$, dengan faktor lain dianggap tetap (cateris paribus). Sebaliknya apabila ada penurunan penggunaan pupuk TSP sebesar 1\% maka akan meningkatkan produksi kelapa sawit sebesar $0,118 \%$. Nilai sig diperoleh sebesar 0,068 (> taraf signifi-kansi 0,05), maka artinya variabel pupuk TSP tidak berpengaruh signifikan (nyata) terhadap produksi kelapa sawit di Desa Sungai Buluh. Hal ini 
dikarenakan dalam penggunaan pupuk yang di berikan petani tidak tepat (waktu, guna dan dosis) akan memberikan dampak yang kurang baik bagi tanaman kelapa sawit tersebut.

Sesuai rekomendasi pupuk dari Litbang Perkebunan penggunaan pupuk TSP yaitu $286 \mathrm{~kg} / \mathrm{garapan} / \mathrm{tahun}$, dan dari hasil yang diperoleh di lapangan petani swadaya menggunakan pupuk TSP yaitu 491 $\mathrm{kg} /$ garapan/tahun, dari hasil perban-dingan tersebut petani swadaya masih belum menggunakan pupuk secara tepat jumlah sehingga akan berpengaruh terhadap produksi kelapa sawit dan dapat menurunkan produksi kelapa sawit tersebut, disarankan bagi petani agar menggunakan jumlah pupuk sesuai rekomendasi supaya dapat menghasilkan produksi yang maksimal.

\section{Pupuk KCl}

Koefisien regresi variabel pupuk KCL diperoleh sebesar 0,001 yang berarti setiap peningkatan penggunaan pupuk KCL sebesar $1 \%$ maka akan meningkatkan produksi kelapa sawit sebesar $0,001 \%$, dengan faktor lain dianggap tetap (cateris paribus). Sebaliknya apabila ada penurunan penggunaan pupuk KCL sebesar $1 \%$, maka akan menurunkan produksi kelapa sawit sebesar $0,001 \%$. Nilai sig diperoleh sebesar 0,982 (> taraf signifikansi 0,05), maka artinya variabel pupuk KCL tidak berpengaruh signifikan (nyata) terhadap produksi kelapa sawit di Desa Sungai Buluh. Sesuai rekomendasi pupuk dari Litbang Perkebunan penggunaan pupuk $\mathrm{KCl}$ yaitu $286 \mathrm{~kg} / \mathrm{garapan} / \mathrm{tahun}$, dan dari hasil yang didapat di lapangan petani swadaya menggunakan pupuk $\mathrm{KCl}$ yaitu 445 $\mathrm{kg} /$ garapan/tahun, dari hasil perbandingan tersebut petani swadaya masih belum menggunakan pupuk secara tepat jumlah sehingga akan berpengaruh terhadap produksi kelapa sawit dan dapat menurunkan produksi kelapa sawit tersebut, disarankan bagi petani agar menggunakan jumlah pupuk sesuai rekomendasi supaya dapat menghasilkan produksi yang maksimal.

Pestisida

Pestisida merupakan bahan yang digunakan untuk mengendalikan, menolak, atau membasmi organisme pengganggu tanaman (OPT) yang berupa hama, gulma dan penyakit. Koefisien regresi variabel pestisida diperoleh sebesar $-0,080$ yang berarti setiap peningkatan penggunaan pestisida sebesar $1 \%$ maka akan menurunkan produksi kelapa sawit sebesar $0,080 \%$, dengan faktor lain dianggap tetap (cateris paribus). Sebaliknya apabila ada penurunan penggunaan pestisida sebesar $1 \%$ maka akan meningkatkan produksi kelapa sawit sebesar $0,080 \%$. Nilai sig diperoleh sebesar 0,077 (> taraf signifikansi 0,05), maka artinya variabel pestisida tidak berpengaruh signifikan (nyata) terhadap produksi kelapa sawit di Desa Sungai Buluh.

Dari hasil yang didapat di lapangan petani swadaya sudah berlebih meng-gunakan pestisida, sehingga hama dan penyakit sudah rentan/kebal terhadap pemberian pestisida, dan tidak akan memberikan dampak yang positif bagi tanaman yang akan menyebabkan produksi menurun.

\section{KESIMPULAN DAN SARAN}

\section{Kesimpulan}

Berdasarkan dari hasil penelitian yang telah dilakukan maka dapat diambil kesimpulan sebagai berikut:

1. Petani kelapa sawit di Desa Sungai Buluh Kecamatan Singingi Hilir memiliki ratarata umur 46,32 tahun, rata-rata tingkat pendidikan petani 9,61 tahun setara SMP, rata-rata jumlah anggota keluarga 4 orang dengan pengalaman berusahatani kelapa sawit 13,84 tahun, sedangkan rata-rata luas lahan petani yaitu sebesar 3,63 ha,

2. Rata-rata biaya produksi yaitu sebesar Rp. 40.227.034/garapan/tahun yang terdiri dari biaya variabel Rp. 39.818.783 /garapan/tahun, dan biaya tetap $\mathrm{Rp}$ 408.251/garapan/tahun). Rata-rata pro duksi TBS sebanyak $64.740 \mathrm{~kg}$ per tahun dengan harga jual rata-rata senilai $\mathrm{Rp}$ $1.449 / \mathrm{kg}$. Pendapatan kotor yaitu sebesar Rp. 93.813.371/garapan /tahun, sedang kan pendapatan bersih diperoleh sebesar $\mathrm{Rp}$ 53.586.337/garapan /tahun. Usaha tani kelapa sawit di Desa Sungai Buluh menguntungkan dan layak untuk diusa hakan dengan nilai efisiensi atau RCR (Return Cost Ratio) sebesar 2,33.

3. Faktor-faktor yang berpengaruh nyata terhadap produksi kelapa sawit di Desa Sungai Buluh Kecamatan Singingi Hilir adalah luas lahan dan pupuk urea. Sedangkan variabel tenaga kerja pupuk TSP, pupuk $\mathrm{KCl}$ dan pestisida tidak berpengaruh signifikan terhadap produksi kelapa sawit. 


\section{Saran}

Saran yang bisa diberikan dalam penelitian ini adalah sebagai berikut:

1. Dari hasil penelitian pendidikan petani harus ditingkatkan lagi supaya petani lebih mengetahui cara bertani kelapa sawit agar memperoleh produksi yang maksimal lagi.

2. Diharapkan bagi pemerintah memberikan penyuluhan yang intensif kepada petani kelapa sawit agar petani menggunakan faktor produksi yang optimal. Dan juga petani diberikan subsidi pupuk karena dari hasil penelitian pupuk dapat meningkatkan hasil produksi kelapa sawit, dan beberapa input harus dikurangi penggunaannya supaya produksi dapat maksimal.

\section{DAFTAR PUSTAKA}

Badan Pusat Statistik Kabupaten Kuantan Singingi. 2016. Kabupaten Kuantan Singingi dalam Angka. Taluk Kuantan.

Dinas Perkebunan Provinsi Riau. 2014. Luas Areal dan Produksi Kelapa Sawit Kabupaten /Kota. Pekanbaru.

Direktorat Jenderal Perkebunan. 2015. Luas Lahan dan Produksi Kelapa Sawit Menurut Provinsi. Jakarta.

Hernanto, F. 1991. Ilmu Usaha Tani. Cetakan pertama. Penerbit. Penebar Swadaya, Jakarta.

Hernanto, F. 1996. Ilmu Usahatani. Penebar Swadaya, Jakarta.

Heriyanto, H., \& Darus, D. (2017). Analisis Efisiensi Faktor Produksi Karet di Kabupaten Kampar Provinsi Riau. Dinamika pertanian, 33(2), 1-10.

Heriyanto, H., Karya, D., Choanji, T., Asrol, A., Bakce, D., \& Elinur, E. (2019). Regression Model in Transitional Geological Environment For Calculation Farming and Production of Oil Palm Dominant Factor in Indragiri Hilir Riau Province. Journal of Geoscience, Engineering, Environment, and Technology, 4(1), 56-65.
Heriyanto, H. (2016). Perilaku Konsumsi Pangan Sumber Karbohidrat Rumahtangga Petani Kelapa Sawit Di Kecamatan Kandis Kabupaten Siak. Jurnal Ilmiah Pertanian, 13(1), 22-30.

Heriyanto, H., Asrol, A., Karya, D. and Ningsih, V.Y., 2018. Analisis Faktor Produksi Kalapa Sawit Rakyat Menurut Tipologi Lahan di Kabupaten Indragiri Hilir Provinsi Riau. Jurnal Lahan Suboptimal, 7(1).

Ningsih, V., Wahyuni, N., Suryati, N., Noviyanto, N., \& Heriyanto, H. (2020). Competitiveness Sensitivity of Oil Palm Farming on Suboptimal Land at Musi Rawas Residence. Journal of Applied Agricultural Science and Technology, 4(1), 26-35. https:// doi.org/10.32530/jaast.v4i1.147. https://kinfopolitani.com/index.php/ JAAST/issue/view/8

Soekartawi. 1995. Analisis Usahatani. UIPress, Jakarta. 